\title{
Assessment of Fungal Pathogens Affecting the Weed Conyza bonariensis in Argentina
}

\author{
Martin Bonacci ${ }^{1,4}$, Ángela N. Formento ${ }^{2}$, Fernando Daita ${ }^{3}$, Melina Sartori ${ }^{1,4}$, Miriam Etcheverry ${ }^{1,4}$, \\ Andrea $\mathrm{Nesci}^{1,4}$ \& Germán Barros ${ }^{1,4}$ \\ ${ }^{1}$ Departamento de Microbiología e Inmunología, Facultad de Ciencias Exactas Físico Químicas y Naturales, \\ Universidad Nacional de Río Cuarto, Río Cuarto, Córdoba, Argentina \\ ${ }^{2}$ INTA-EEA Paraná, Oro Verde, Entre Ríos, Argentina \\ ${ }^{3}$ Facultad de Agronomía y Veterinaria, Universidad Nacional de Río Cuarto, Río Cuarto, Córdoba, Argentina \\ ${ }^{4}$ Consejo Nacional de Investigaciones Científicas y Técnicas (CONICET), Argentina \\ Correspondence: Germán Barros, Laboratorio de Ecología Microbiana Ambiental, Departamento de \\ Microbiología e Inmunología, Facultad de Ciencias Exactas Físico Químicas y Naturales, Universidad Nacional \\ de Río Cuarto, Ruta Nacional No 36 Km 601 (5800) Río Cuarto, Córdoba, Argentina. Tel: 54-358-467-6231. \\ E-mail: gbarros@exa.unrc.edu.ar
}

Received: December 7, 2017

Accepted: January 21, $2018 \quad$ Online Published: February 15, 2018

doi:10.5539/jas.v10n3p62

URL: https://doi.org/10.5539/jas.v10n3p62

\begin{abstract}
In the last years Conyza bonariensis has become an important weed and control is difficult with the use of current technology in Argentinean pampas region. The increasing prevalence of herbicide-resistant weed species, public concern related to pesticide use and the introduction of government policies for pesticide reduction, is driving the search for alternative methods to chemical control. The aims of the present study were to detect fungal diseases associated with $C$. bonariensis, to identify fungal isolates from the symptomatic leaves and to confirm through Koch's postulates the isolates pathogenicity. Mycological analysis of symptomatic leaves showed the presence of twelve genera of filamentous fungi. Among 116 isolates, Colletotrichum spp. was the most prevalent genus followed by Nigrospora spp. and Septoria spp. In the pathogenicity assays, 22 out of 116 isolates were able to comply with the Koch's postulates. The pathogenic isolates were included into three genera Alternaria spp., Colletotrichum spp. and Septoria spp. This study provides the first report that demonstrates pathogenicity of fungal isolates on C. bonariensis in Argentina and represents the first step in a future biocontrol program.
\end{abstract}

Keywords: Conyza bonariensis, foliar, disease, fungal pathogens

\section{Introduction}

Over the past 25 years Argentina has adopted a productive model based on no-tillage cultivation with scarce or no crops rotation, herbicide overuse with glyphosate predominance and mainly lack of awareness, which has led to weed shift towards difficult to control species and evolution of herbicides resistance (Papa \& Tuesca, 2014a). Thus, the number of herbicide-resistant weeds increased markedly in recent years in Argentina, with a rate of 4 biotypes per year with a total of 30 resistant biotypes already confirmed (Acciaresi et al., 2017).

Conyza bonariensis L. Cronquist (Asteraceae) is an annual herb native to South America with abundant presence in Argentina, Uruguay, Paraguay and Brazil (Kissmann \& Groth, 1991). This is an annual species that is multiplied by seeds, which germinate mainly in autumn and winter, although a small percentage of seeds are capable of germinating during spring. Conyza bonariensis complete their cycle in spring-summer being a cosmopolitan weed present in pastures, annual winter crops, fallows and summer crops, mainly soyabean under reduced and no-tillage system (Leguizamón, 2011). In recent years, this species has appeared in the Argentinean pampas region as an important weed and it is becoming difficult to control using current technology. Furthermore, populations of $C$. bonariensis have been confirmed recently as resistant to glyphosate (Puricelli, Faccinni, \& Metzler, 2015). In Argentina several herbicides mixes and sequential applications (double-knock) provide good seedling control, but herbicide performance depends largely on weed size, age, density and growing conditions at spraying. Correct timing of herbicide application is essential for effective C. bonariensis 
control. It is crucial to apply herbicides when the plant is a small rosette, preferably of $5 \mathrm{~cm}$ in diameter or smaller, and definitely prior to stem elongation until $15 \mathrm{~cm}$, as control efficacy declined as plants mature (Metzler, Puricelli, \& Papa, 2013; Papa, Tuesca, \& Nisensohn, 2010). However, under the current production model more than $60 \%$ of the agricultural area in Argentina is under rental with very short term contracts. As a result there is a late start of activities and weeds control is often carried out late to be treated effectively with normal doses of herbicides available. Conyza bonariensis is characterized as extremely aggressive weed in soybean and can cause 50\% or more yield losses if left uncontrolled (Papa \& Tuesca, 2014b). Integrated Weed Management (IWM) is defined as the integration of different control methods to provide the crop with an advantage over the weeds (Lamichhane et al., 2017). It is practiced worldwide with different adoption levels and is intended to restrict weed populations to manageable levels, to reduce the environmental impact of individual practices, to increase the sustainability of cropping systems and to reduce selection pressure for weed resistance to herbicides. However, published articles on chemical control since 1995 are the most numerous compared to any other method of weed control (Harker \& O'Donovan, 2013).

Considering the general trend to reduce the entry of synthetic pesticides in the agroecosystem, it is necessary to search biological alternatives for example through the use of bioherbicides considered to be a type of inundative biological control. This biological weed control is relevant to the needs of agriculture and turf management, as it can be implemented through the application of inoculum as liquid sprays or solid granules in a similar way to conventional herbicides (Auld, Hetherington, \& Smith, 2003). On the other hand, phytopathogenic fungi can be used as producers of bioactive molecules with herbicidal activity (Castro de Souza et al., 2017). Many steps are involved in the implementation of a biological control program but it always includes surveys aimed at identifying the natural enemies associated with the plant in its centre of origin and often also comprises surveys in the region where introductions will be made (Duarte, Santos, \& Barreto, 2016). However, no systematic surveys have been carried out on C. bonariensis for suitable agents as it was suggested by Scott et al. (2016). Based on this context, the aims of the present study were: i) to detect fungal disease associated to C. bonariensis; ii) to identify fungal isolates from the symptomatic leaves; iii) to confirm through Koch's postulates the isolates pathogenicity.

\section{Method}

\subsection{Sampling Sites and Leaves Symptoms Analysis}

Samples were collected during the periods 2015 and 2016 growing season in experimental fields at the Universidad Nacional de Río Cuarto (3306 $31.6^{\prime \prime} \mathrm{S} ; 64^{\circ} 18^{\prime} 01.3^{\prime \prime}$ W) (Río Cuarto, Córdoba). Within this area survey sites were arbitrarily selected according the occurrence of weed populations in the production crops, pastures areas, etc. Whenever diseased plants were found, representative parts bearing symptoms were taken and referenced. In the laboratory, infected plant tissues were observed under a magnifying glass (Motic, model DM-39-N9GO) to observe signs, i.e. the presence of fungal structures such as fruiting bodies, conidiophores, sclerotia, etc., establishing associations between signs and disease symptoms. Symptoms on leaves were classified as: central, apical or lateral blight and/or leaf spots. Symptoms were rated using a 0-4 scale according to the approximate leaf blight severity area: $0=0 \%, 1=1-10 \%, 2=11-25 \%, 3=26-40 \%, 4 \geq 40 \%$ (Figure 1). To calculate the percentage of affected leaf an ImageJ 1.51 program was used (Schneider, Rasband, \& Eliceiri, 2012). 


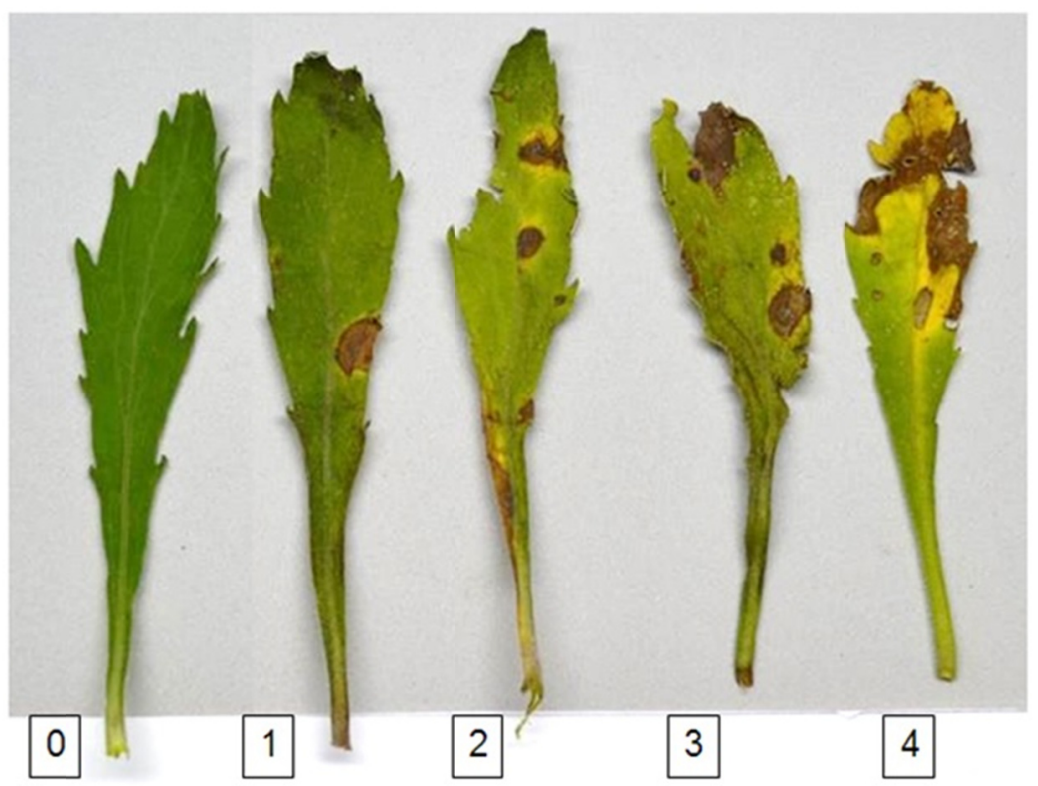

Figure 1. Ordinal scale according to the approximate leaf blight severity area: $0=0 \%, 1=1-10 \%, 2=11-25 \%, 3$ $=26-40 \%, 4=40 \%$

\subsection{Fungal Isolation and Identification}

The symptomatic leaves were surface disinfected for 1 minute in ethanol $75 \%$, then, for $1 \mathrm{~min}$ in $3 \%$ sodium hypochlorite $(\mathrm{NaOCl})$ solution, rinsed three times in sterile distilled water and blotted dry on sterile paper towels in laminar flow chamber for $10 \mathrm{~min}$ (Agrios, 2005). The fungal isolation was carried out using two methods. On the one hand, symptomatic leaves were placed in moist chambers to allow the pathogen to grow out on the tissue. Then, the isolation in pure cultures were attempted by the direct transfer of spores or other fungal structures using a sterile fine pointed needle onto plates containing potato dextrose agar (PDA) acidified with $25 \%$ lactic to pH 5 acid amended with streptomycin $\left(100 \mathrm{mg} \mathrm{L}^{-1}\right)$ (Pioli, Gattuso, Prado, \& Borghi, 1997). Incubation was carried out at $25 \pm 1{ }^{\circ} \mathrm{C}$ and complete darkness for five to seven days. In the second isolation method, small sections of approximately $10 \mathrm{~mm}$ square were cut from the margin of the infected lesion so that they contain both disease and healthy-looking tissue (Agrios, 2005) and transferred aseptically to Petri dishes containing PDA acidified with lactic acid $25 \%$ amended with streptomycin $\left(100 \mathrm{mg} \mathrm{L}^{-1}\right)$. The plates were incubated in complete darkness for at least 10 days at $25 \pm 1{ }^{\circ} \mathrm{C}$. Single-spored cultures from colonies were transferred to PDA and were further identified based on macromorphology and micromorphology according to Barnett and Hunter (1998).

\subsection{Pathogenicity Assays}

Inoculum production was prepared by growing each isolate on PDA medium and incubated for at least 15 days at $25 \pm 1{ }^{\circ} \mathrm{C}$. After this period, conidia were collected by flooding the Petri dish with sterile water and washing them off the media surface. The conidial suspension was filtered through three layers of cheesecloth to reduce the amount of mycelial or other structures. The filtered conidial concentration was determined in a Neubauer chamber (Marienfeld-Superior, Germany) under an optical microscope (Carls Zeiss; Model Primo Star Trinocular) and diluted to obtain $10^{7}$ conidia/mL. Seedlings of $C$. bonariensis were inoculated at rosette stage (approximately $5 \mathrm{~cm}$ in diameter) by brushstroke with a suspension of approximately $10^{5}$ conidia/mL supplemented with corn oil to final concentration of $0.01 \%$ for better adherence of inoculum to the leaf tissue. Inoculation treatment consisted of a total of six plants by isolate and every experiment was repeated twice in the independent way. For each isolate were utilized two injured plants inoculated with conidia, two plants without injury inoculated with conidia and two plants without injury inoculated with sterile water as negative controls. After inoculation, the plants were placed in a humidity chamber for $72 \mathrm{hs}$ at $25{ }^{\circ} \mathrm{C}$ and $90 \% \mathrm{RH}$, and then transferred to a greenhouse maintained approximately at $25^{\circ} \mathrm{C}$. After 14 days, plants were removed by hand and transported to the laboratory for more accurate and detailed studies. Leaves were visually assessed for blight severity and the symptomatic leaves were transferred to Petri dishes containing PDA acidified whit lactic acid $25 \%$ amended with streptomycin $\left(100 \mathrm{mg} \mathrm{L}^{-1}\right)$ and identified by morphology according to Barnett and Hunter (1998) to complete Koch`s postulates. 


\section{Results}

In most cases where the diseased plants of $C$. bonariensis were detected, the symptoms were observed on living leaves. The most common necrotic symptom on leaves was blight with variable sizes and position showing tissue from dark brown to black and less regularly bluish purple color with yellow-green center or necrotic spots (Figures $2 \mathrm{~A}$ and $2 \mathrm{~B}$ ). The lesion edges were smooth or irregular, with or without a chlorotic periphery, sometimes thin to more conspicuous. In some cases, signs were observed on the leaf surface with the presence of fruiting bodies (Figures 2C and 2D). A total of 344 symptomatic leaves were analyzed, in which the most common lesions were apical and lateral blight showing frequencies about $49 \%(n=168)$ and $27 \%(n=92)$ respectively. The leaves with symptoms representing central blight and leaf spot showed lower frequency, $22 \%$ $(\mathrm{n}=75)$ and $3 \%(\mathrm{n}=9)$ respectively. Respect to leaf blight severity, lesions grade 2 (up to $25 \%$ of affected leaf area) were the most frequent in the $40 \%$ of analyzed leaves, followed by lesions grade 3,4 and 1 with $23 \%, 19 \%$ and $18 \%$, respectively. The mean disease severity among the total leaves evaluated was around $26.13 \%$.

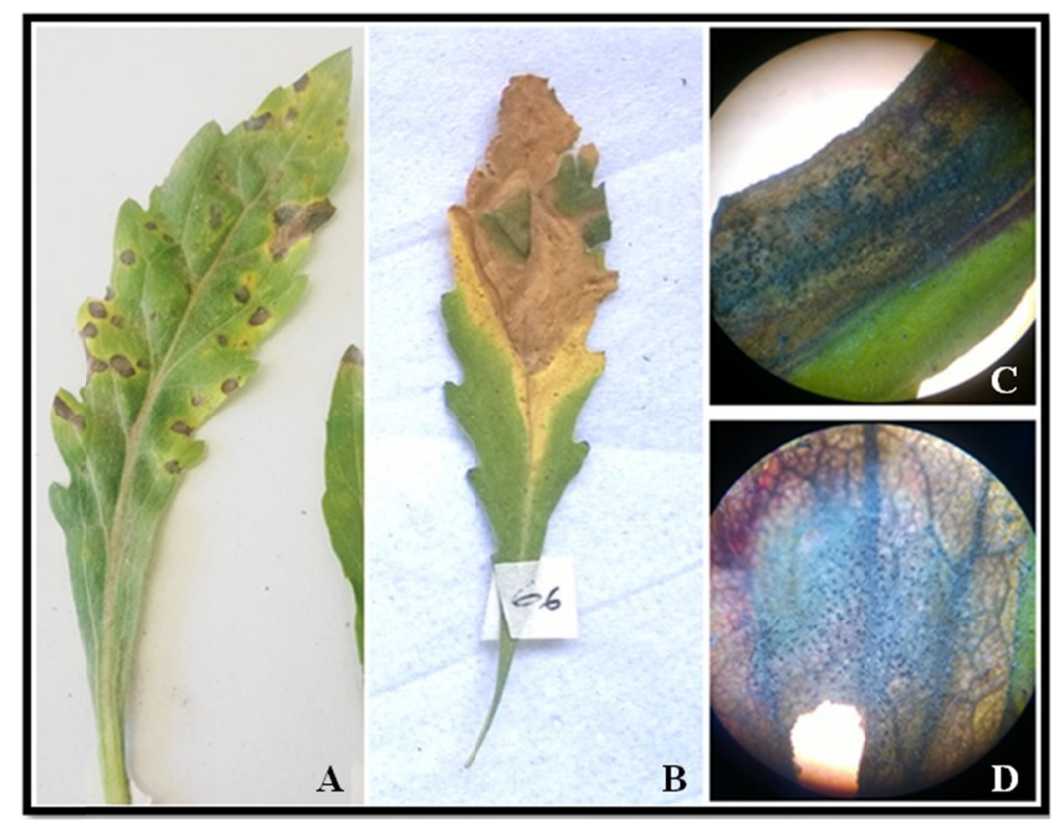

Figure 2. Leaf spots (A) and blight (B) on Conyza bonariensis. Presence of fruiting bodies (Pycnidia) of Septoria spp. (C, D)

Mycological analysis of symptomatic leaves showed the presence of twelve genera of filamentous fungi. Among the 116 isolates, Colletotrichum spp. was the most prevalent genus with $30.2 \%$ of isolates followed by Nigrospora spp. and Septoria spp. account the $15.5 \%$ and $13.8 \%$ of isolates respectively (Figure 3 ). 


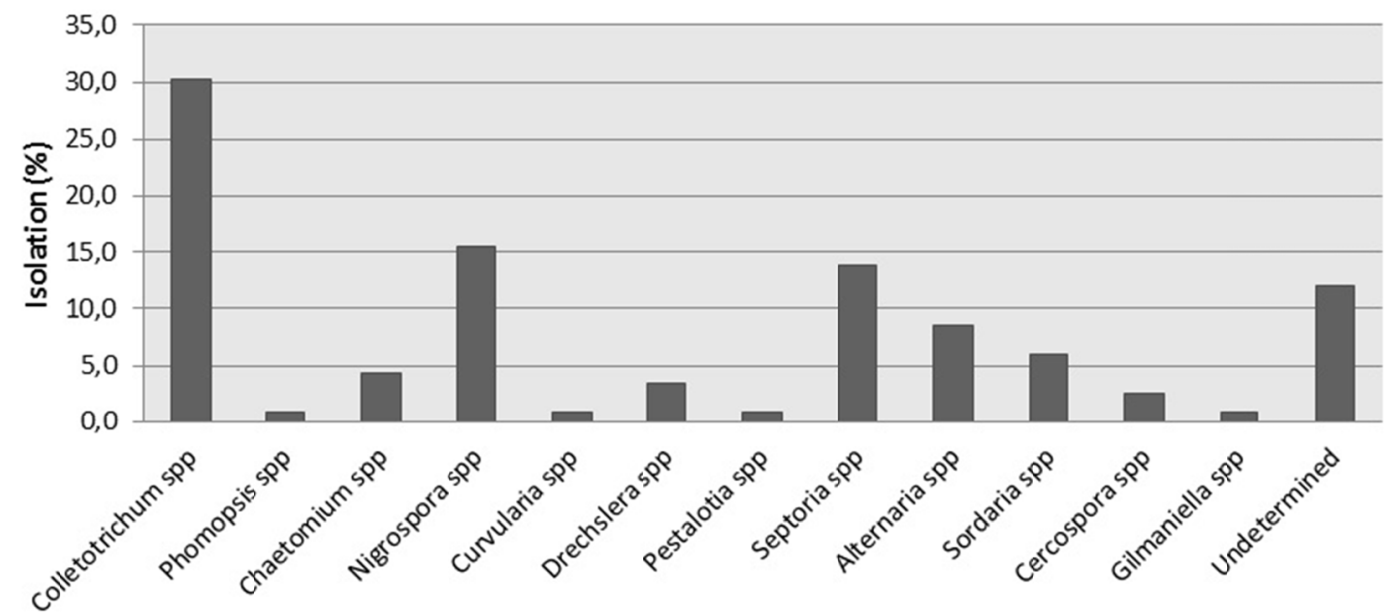

Figure 3. Isolation frequency of fungal genera isolated from symptomatic leaves of Conyza bonariensis

Not all isolates belonging to twelve genera recovered from symptomatic leaves were able to develop diseases at leaf level. In the pathogenicity assays, 22 out of 116 isolates (19\%) were able to comply with the Koch's postulates. The pathogenic isolates were included into three genera Alternaria spp., Colletotrichum spp. and Septoria spp. Two isolates belonging to Alternaria genus were pathogenic for C. bonariensis seedling. Lesions were characterized by necrotic lesions with smooth or irregular edges, brown in color with or without a chlorotic periphery (Figures 4A, 4B, and 4C). The visualization time of lesions was 4 to 7 days after inoculation and the lesion size grew until, in some cases, necrotizing all foliar surface. Similar visualization time of lesions was observed in pathogenic Colletotrichum isolates. In this case, necrotic lesions were irregular, dark brown more frequently located in the leaf margins (lateral or apical) (Figures 4D, 4E, and 4F). Thirteen out of 35 Colletotrichum isolates were able to caused symptoms in the pathogenicity test only in injured leaves and only one isolate induced the seedlings death. Regarding the pathogenic Septoria isolates, the visualization time of the lesions was significantly lower than those observed in the pathogenic Alternaria and Colletotrichum isolates (24 to $48 \mathrm{hs}$ after inoculation). Lesions on leaves were concentric, circular, brown color with edges smooth and defined (Figures 4G, 4H, and 4I). In some cases conidiomata pycnidial were observed adaxially. Although all pathogenic Septoria isolates (8 strains) showed varying levels of severity, they were all able to develop symptoms on both damaged and healthy leaves. On other hand, all isolates belonging to the genera such as Cercospora spp., Chaetomium spp., Curvularia spp., Drechslera spp., Gilmaniella spp., Nigrospora spp., Pestalotia spp., Phomopsis spp., Sordaria spp. and the undetermined isolates did not comply with the Koch's postulates and they were not able to develop symptoms even when leaves were injured. 


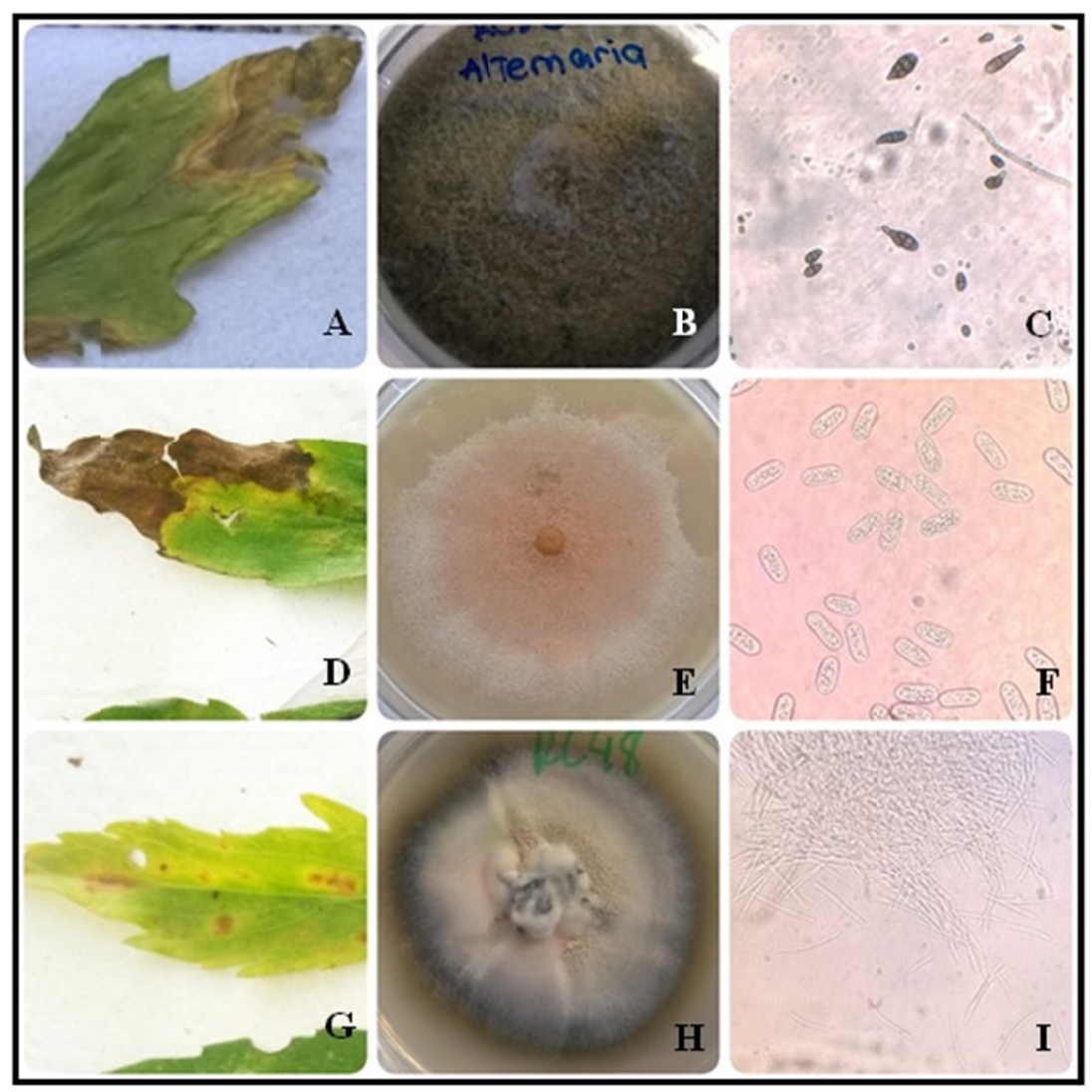

Figure 4. Alternaria spp. on Conyza bonariensis A) Leaf necrosis B) Colony on PDA C) Conidia. Colletotrichum spp. on Conyza bonariensis D) Necrotic lesions E) Colony on PDA F) Conidia. Septoria spp. on Conyza bonariensis G) Leaf spots H) Colony on PDA I) Conidia

\section{Discussion}

Conyza bonariensis has become difficult to control weed in Argentinean pampas region favored by absence or lack of weed scouting, lack of crop rotation or soyabean monoculture and the use of herbicides as main management strategy (Papa \& Tuesca, 2014a). From a perspective of sustainability it is necessary to develop alternative controls that allow reducing the synthetic herbicide dependence. In this sense, the biological control through the use of a mycoherbicide could be a good option within the framework of an integrated weed management program to increase the weed control efficiency.

A first step in developing a mycoherbicide is the search for fungal pathogens that can cause disease in target weeds. To date, several studies have investigated the mycobiota associated to several Conyza species (Duarte et al., 2016; Liu et al., 2012; Pirnia et al., 2012; Caretta et al., 1999; Roy et al., 1994; Lindquist, 1982). However, few researches performed pathogenicity assays to confirm the pathogenic effect of the isolates detected in the weed species (Liu et al., 2012).

In this work, an $81 \%$ of the isolates recovered from symptomatic leaves don't comply with Koch's postulates. These isolates could be considered saprophytic fungi that do not cause direct damage to weed such as some Alternaria spp., Phoma spp., Nigrospora spp., Chaetomium spp. and Curvularia spp. isolates (Caretta et al., 1999) or secondary colonizers of leaves damaged by other fungi or by insects. In Argentina, soybean often is used in rotation with wheat and other cereal crops in a reduced or no-till system. So soybean pathogen such as Phomopsis spp. or Cercospora spp. isolated in this work from C. bonariensis, can use this weed as an alternative host and to provide an inoculum source for crop infections in subsequent year (Ferreira da Silva et al., 2011).

In the present work, 22 isolates belonging to three genera were pathogens for $C$. bonariensis and fulfilling with Koch's postulates; therefore these isolates could be considered potential candidates to be included in a biocontrol program. Alternaria is a very ubiquitous genus in the environment considered as a common primary colonizer of leaves in a variety of plants. However, some species affect leaves, stems, flowers and fruits of annual plants, 
vegetables, ornamental plants and fruit trees as citric and apple tree (Agrios, 2005). Previous studies demonstrated saprophytic associations between Alternaria and Conyza species (Caretta et al., 1999; Roy et al., 1994) or related the fungal presence to lesion on leaves (Duarte et al., 2016). In this study, 2 out 10 Alternaria isolates were able to develop symptoms in $C$. bonariensis and were subsequently isolated from all lesions. Until now, there is only one worldwide registered bioherbicide called Smoulder ${ }^{\circledR}$ based on A. destruens L. Simmons strain 059. This fungus is parasitic on cuscuta's species and can be apply in crops as alfalfa, carrot, tomato and ornamental plants in USA (Bailey, 2014).

The Colletotrichum genus was the most frequently isolated from symptomatic leaves of $C$. bonariensis. Similar results were obtained by Roy et al. (1994), and Formento (2013), who demonstrated the presence of Colletotrichum or Glomerella isolates from foliar lesions of Conyza spp. The lesions were similar to those observed in Alternaria isolates; however in the pathogenicity tests a $37 \%$ of the isolates were able to develop symptoms and could be recovered from affected tissues. Numerous researches showed association between Colletotrichum species and weed biocontrol and some of them have been registered such as Collego®/ LockDown ${ }^{2}, C$. gloeosporioides $f$. sp. aeschynomene ATCC 20358 utilized to control Aeschynomene virginica in rice in USA (Bowers, 1986) and Biomal ${ }^{\circledR}$, Colletotrichum gloeosporioides $f$. sp. malvae ATCC 20767 used to control broadleaf weeds in the family Malvaceae Malva in Canadá (Boyetchko, Bailey, Hynes, \& Peng, 2007).

The third genus that demonstrated pathogenicity in $C$. bonariensis was represented by isolates belonging to Septoria spp. In this case, all isolates recovered from symptomatic leaves reproduced the disease in pathogenicity tests showing similar aggressiveness. Previous works worldwide have detected diseases in Conyza related to the presence of Septoria species (Duarte et al., 2016; Erper et al., 2010; Priest, 2006; Fatehi et al., 1993). On the other hand, several investigations have reported the use of different Septoria species as biocontrol agents such as $S$. cirsii in Cirsium arvense, a weed of Asteraceas's family (Leth, 1985), S. polygonorum proposed against species of Polygonum (Mitchell, 2003) and S. urticae proposed against Urtica urens L. (Bello, Perelló, \& Monaco, 1993).

Taking into account that isolates from three genera pathogenic to $C$. bonariensis have been used as bioherbicides worldwide, such strains could be considered potential candidates as weed biocontrol agents. On the other hand, we know that some Septoria species and others belonging to the Colletotrichum species complex include pathogens in several crops such as soyabean, maize, wheat, sorghum and grasses (Agrios, 2005). These pathogens can survive in the host absence through the use of alternative hosts as weeds or living as saprophytic on crop residues. For this reason, before including a strain into a biocontrol program of C. bonariensis it is necessary to evaluate the environmental risk of the potential bioherbicide using scientific criteria through the evaluation of host specificity, crop tolerance, environmental fate and toxicology. Changes in the public's attitude on the acceptance of synthetic herbicides (and all pesticides) and the introduction of government policies for pesticide reduction, represent an opportunity for the development of new weed control technologies that have reduced risks and are suitable for organic food production (Bailey, 2014). Thus, although only a limited number of isolates were evaluated in the present study, this is the first report that demonstrates pathogenicity of fungal isolates on $C$. bonariensis in Argentina and represents the first step in a future biocontrol program into integrated weed management.

\section{Acknowledgements}

This work was supported by grants from Secretaría de Ciencia y Técnica, Universidad Nacional de Río Cuarto (SECyT-UNRC PPI 2016-2018) and Agencia Nacional de Promoción Científica y Tecnológica (PICT 2102/16).

\section{References}

Acciaresi, H., Baigorria, T., Bertolotto, M., De la Fuente, E., De la Vega, M., García Frugoni, F., ... Vigna, M. (2017). Manejo de malezas a 10 años. Aapresid. Retrieved from https://www.aapresid.org.ar/rem/manejode-malezas-a-10-anos/

Agrios, G. N. (2005). Plant pathology (5th ed.). San Diego, California, USA: Elsevier Academic Press.

Auld, B. A., Hetherington, S. D., \& Smith, H. E. (2003). Advances in bioherbicide formulation. Weed Biology and Management, 3, 61-67. https://doi.org/10.1046/j.1445-6664.2003.00086.x

Bailey, K. L. (2014). The bioherbicide approach to weed control using plant pathogens. In D. P. Abrol (Ed.), Integrated pest management: Current concepts and ecological perspective (pp. 245-266). San Diego, Elsevier. https://doi.org/10.1016/B978-0-12-398529-3.00014-2

Barnett, H. L., \& Hunter, B. B. (1998). Illustrated genera of imperfect fungi (4th ed.). St. Paul, USA: American Phytopathological Society (APS Press). 
Bello, G. M., Perelló, A. E., \& Monaco, C. I. (1993). Preliminary evaluation of Septoria urticae Rob. et Desm. as a biological control agent of Urtica urens L. Agronomie, 13(2), 121-124. https://oi.org/10.1051/ agro:19930206

Bowers, R. (1986). Commercialization of Collego ${ }^{\mathrm{TM}}$-An industrialist's view. Weed Science, 34(S1), $24-25$. https://doi.org/10.1017/S0043174500068326

Boyetchko, S. M., Bailey, K. L., Hynes, R. K., \& Peng, G. (2007). Development of the mycoherbicide, BioMal®. Biological control: A global perspective (pp. 274-283). Wallingford, UK: CABI. https://doi.org/10.1079/ 9781845932657.0274

Caretta, G., Piontelli, E., Picco, A. M., \& Del Frate, G. (1999). Some filamentous fungi on grassland vegetation from Kenya. Mycopathologia, 145(3), 155-169. https://doi.org/10.1023/A:1007038112075

Castro de Souza, A. R., Baldoni, D. B., Lima, J., Porto, V., Marcuz, C., Machado, C., ... Mazutti, M. A. (2017). Selection, isolation, and identification of fungi for bioherbicide production. Brazilian Journal of Microbiology, 48(1), 101-108. https://doi.org/10.1016/j.bjm.2016.09.004

Duarte, L. L., Santos, F. M. C., \& Barreto, R. W. (2016). Mycobiota of the weed Conyza canadensis (Asteraceae) in Brazil. Fungal Biology, 120(9), 1118-1134. https://doi.org/10.1016/j.funbio.2016.05.015

Erper, I., Tunali, B., \& Berner, D. K. (2010). First report of leaf spot on horseweed (Conyza canadensis) caused by Septoria erigerontis in Turkey. Plant Disease, 94(7), 918-918. https://doi.org/10.1094/PDIS-94-7-0918C

Fatehi, J., Hedjaroude, G. A., \& Ershad, D. (1993). Studies on Septoria species in Iran-I. Iranian Journal of Plant Pathology, 29, 25-29.

Ferreira da Silva, A., Galon, L., Aspiazú, I., Alves Ferreira, E., \& Concenco, G. (2011). Safety aspects in soybean food and feed chains: Fungal and mycotoxins contamination. Soybean -Biochemistry, Chemistry and Physiology (pp. 85-112). Rijeka, Croatia: InTech-Open Access Publisher.

Formento, N. Á. (2013). Detección de cuatro enfermedades foliares en “ rama negra " (Conyza bonariensis) en Entre Ríos. Entre Ríos, Argentina. Retrieved from https://inta.gob.ar/documentos/deteccion-de-cuatro-enfer medades-foliares-en-rama-negra-conyza-bonariensis-en-entre-rios

Harker, N. K., \& O’Donovan, J. T. (2013). Recent weed control, weed management and integrated weed management. Weed Technology, 27(1), 1-11. https://doi.org/10.1614/WT-D-12-00109.1

Kissmann, K. G., \& Groth, D. (1991). Plantas infestantes e nocivas (2nd ed.). São Paulo, Brasil: Basf Brasileira.

Lamichhane, J. R., Devos, Y., Beckie, H. J., Owen, M. D. K., Tillie, P., Messéan, A., \& Kudsk, P. (2017). Integrated weed management systems with herbicide-tolerant crops in the European Union: lessons learnt from home and abroad. Critical Reviews in Biotechnology, 37(4), 459-475. https://doi.org/10.1080/ 07388551.2016.1180588

Leguizamón, E. S. (2011). Problemas, manejo de malezas. Santa Fe, Argentina: Aapresid. Retrieved from http://www.aapresid.org.ar/rem/manejo-de-malezas-problema-rama-negra/

Leth, V. (1985). Inventor of Patent "Herbicide containing phytotoxic fungal material from Phomopsis cirsii or Septoria cirsii, especially for control of Compositae". Patent no. EP 13685A, AU 8432760A, NO 8403545A, FI 8403493A, J 60084207A, DK 8404254A, ZA 8407001A, US 4753670A, CAT 247879A, DE 3475745G, EP $136850 B$.

Lindquist, J. C. (1982). Puccinia striiformis (Triricum aestium). Royas de la República Argentina y zonas limitrofes (pp. 243-574). Buenos Aires, Argentina: Instituto Nacional de Tecnologia Agropecuaria (INTA). Colección Cientifica.

Liu, J., Luo, H. D., Tan, W. Z., \& Hu, L. (2012). First report of a leaf spot on Conyza sumatrensis caused by Phoma macrostoma in China. Plant Disease, 96(1), 148-148. https://doi.org/10.1094/PDIS-03-11-0228

Metzler, M., Puricelli, E., \& Papa, J. C. (2013). Manejo y control de rama negra. Retrieved from http:/www.aapresid.org.ar/wp-content/uploads/sites/3/2013/10/Metzler.-Manejo-y-control-de-Rama-negra

Mitchell, J. K. (2003). Development of a submerged-liquid sporulation medium for the potential smartweed bioherbicide Septoria polygonorum. Biological Control, 27(3), 293-299. https://doi.org/10.1016/S10499644(03)00024-0

Papa, J. C., \& Tuesca, D. (2014a). El doble golpe como táctica para controlar malezas “dificiles”. Retrieved from https://inta.gob.ar/documentos/el-doble-golpe-como-tactica-para-controlar-malezas-dificiles-caracteris 
ticas-de-una-tecnica-poco-comprendida

Papa, J. C., \& Tuesca, D. (2014b). Los problemas actuales de malezas en la región sojera nucleo argentina: Origen y alternativas de manejo. Para Mejorar la Producción, 52. Rosario, Argentina. Retrieved from https://inta.gob.ar/documentos/los-problemas-actuales-de-malezas-en-la-region-sojera-nucleo-argentina-ori gen-y-alternativas-de-manejo

Papa, J. C., Tuesca, D., \& Nisensohn, L. (2010). Control tardío de rama negra (Conyza bonariensis) sobre individuos sobrevivientes a un tratamiento previo con glifosato. Para mejorar la producción, 45. Retrieved from https://inta.gob.ar/documentos/control-tardio-de-rama-negra-conyza-bonariensis-sobre-individuos-sob revivientes-a-un-tratamiento-previo-con-glifosato

Pioli, R., Gattuso, S., Prado, D., \& Borghi, A. (1997). Recent outbreak of stem canker (Diaporthe phaseolorum var. meridionalis) of soybean in Santa Fe, Argentina. Plant Disease, 81(10), 1215. https://doi.org/10.1094/ PDIS.1997.81.10.1215A

Pirnia, M., Zare, R., Zamanizadeh, H. R., \& Khodaparast, A. (2012). New records of cercosporoid hyphomycetes from Iran. Mycotaxon, 120, 157-169. https://doi.org/10.5248/120.157

Priest, M. J. (2006). Fungi of Australia: Septoria. Canberra, Australia: Australian Biological Resources Study.

Puricelli, E., Faccinni, D., \& Metzler, M. (2015). ALERTA: Conyza sumatrensis y Conyza bonariensis resistentes a glifosato en la provincia de Entre Ríos. Entre Ríos, Argentina. Retrieved from https://www. aapresid.org.ar/rem/conyza-sumatrensis-y-conyza-bonariensis-rama-negra/

Roy, K. W., Miller, W. A., \& McLean, K. S. (1994). Survey of pathogenic genera of fungi on foliage of weeds in Mississippi. Canadian Journal of Plant Pathology, 16, 25-29. https://doi.org/10.1080/07060669409500784

Schneider, C. A., Rasband, W. S., \& Eliceiri, K. W. (2012). NIH Image to ImageJ: 25 years of image analysis. Nature Methods, 9(7), 671-675. https://doi.org/10.1038/nmeth.2089

Scott, J. K., Yeoh, P. B., \& Michael, P. J. (2016). Methods to select areas to survey for biological control agents: An example based on growth in relation to temperature and distribution of the weed Conyza bonariensis. Biological Control, 97, 21-30. https://doi.org/10.1016/j.biocontrol.2016.02.014

\section{Copyrights}

Copyright for this article is retained by the author(s), with first publication rights granted to the journal.

This is an open-access article distributed under the terms and conditions of the Creative Commons Attribution license (http://creativecommons.org/licenses/by/4.0/). 